\title{
THE FORGING OF NATIONAL STATES ON THE ANVIL OF WAR
}

\section{Haris Hojkurić*}

Dželal Ibraković*

\begin{abstract}
The progress of Western countries and the colonization of oil-rich Muslim countries clustered within the Ottoman Empire, which was located in the controlled agony of the new geo-strategic and technological processes, produced a turbulent beginning of the 20th century. The establishment of nation states has jeopardized the survival of monarchies such as Austro-Hungary, Russia, and others. The battle for the new, above all, European order signified the World War, in political science but also in historiography, and it established the principle that the term "world" war refers to the conflicts waged in Europe. The First World War was the site scene of the disappearance of the great empires and also the definite disappearance of the juncture of state and religion, as well as suppression of religion and other monarchist structures into new paradigms such as the nation-state, democracy and secularization. On the contrary, it opened the opportunity for the development of totalitarian regimes - socialism and Nazism - created precisely in Europe. Muslim-majority countries were colonized and brought to a vassal state, and their rich natural resources were enslaved. The principle of the nation state was imposed upon them by imperial methods and brutal clashes with opponents, aiming to eliminate in the long term any significant force since the overthrow of the Ottoman Empire and the attempts to destroy Turkey completely. Bosnia and Herzegovina and the Balkans emerge as a collateral damage that lasts even in the $21 \mathrm{st}$ century.
\end{abstract}

Keywords: The "World War" State and Nation; The Balkans; Territory and Conflict

\section{Introduction:}

The $20^{\text {th }}$ century is one of the deadliest centuries in human history. Contemporaries often emphasize that the modern age has successfully brought violence under control although the Great War or the First World War paved the way for a drastic use of violence in this century. British sociologist and one of the most significant interpreters of the last century, Anthony Giddens, will come to conclusion that this century, as so called "the century of modern societies", was, according to the number of its armed conflicts, extremely violent and terrifying. Maid Taherian asserts that

after 1900, there were approximately 250 international and civil wars and as a result 100 million soldiers and around 100 million civilians were killed. By counting only war victims, $18^{\text {th }}$ century had a rate of 50 victims per million residents, in comparison to 60 victims in the $19^{\text {th }}$, and 460 in the $20^{\text {th }}$ century. (By Hersak, 1999: 32-33) 
A small country in Europe, Bosnia and Herzegovina, without any desire of its people, has marked this tendency by which the $20^{\text {th }}$ century will be remembered in history. Events in and around this country marked the beginning and the end of this murderous century. The annexation of Bosnia and the assassination of the Austro-Hungarian Archduke Franz Ferdinand and his pregnant wife Sophia by Gavrilo Princip in Sarajevo in 1914 were the events that introduced and formally launched the First World War. On the other hand, the aggression on Bosnia (1992-1995) was treated as "ethnic conflict" or "civil war" in the Balkans. This country also suffered a tremendous desolation during the Second World War; in any of these cases its citizens, material goods and wealth were exposed to destruction, ruthless killings and plundering.

Scientists are faced with a multiple dilemmas that are not sufficiently clarified, and as a result there are many approaches to them even in the scientific circles. This is corroborated by the controversy concerning the celebration of the $100^{\text {th }}$ anniversary of the assassination attempt in Sarajevo - an entire century from the beginning of the First World War. There is no dilemma, however, about the fact that the criteria for a "world" war only applies to armed conflicts that took place in the European countries. This shows a rule of Euro centrism in social relations in the world.

There are, certainly, other opinions which consider that during the modern age (ongoing) the great war was a constant of human development which only improves the possibilities of destruction, and its objectives as such are not just military any more, but through the forms of national, ideological, religious and individual terrorism it expands itself to a war of all against all. The aim of this work is not to analyze the layers and complexities of international relations and geopolitical games which are present and increasingly gaining certain forms of conspiracy theories, or overemphasized roles of ideology, rigid divisions of the world on East and West or on the "good" and the "bad" guys. Edward Said rightly stated that "every single empire, in its official discourse, has said that it is not like all the others, that its circumstances are special, that it has a mission to enlighten, civilize, bring order and democracy, and that it uses force only as a last resort." Engdahl (1999) points to some of these motives which are not the subject of the adopted and ruling views on the world. In the struggle for the control of strategic resources (energy and oil), he sees the explanation for the events that occurred in the $20^{\text {th }}$ century and also the real causes of major conflicts that happened then and continued in the $21^{\text {st }}$ century.

The socio-historical concept of the $20^{\text {th }}$ century is certainly important because this century brought unimagined achievements in the development of science, especially technology. The world system of capital relations was being established on the global level. The means of production which were mainly related to agriculture were conquering types of feudal empires, and they were never able to achieve any global significance. 
Industrial revolution led to such social changes which, sooner or later, involved global character. The fight for supremacy and control over strategic resources is still directed by the form of nation states.

Nation and nation state is the main product of the new world view, which enables the development of capital relations and it strives to have a dominant influence. Its internal logic of existence is based on the profit and this goal is the guiding principle for the suppression of other forms and spheres of influence. This also applies to the suppression of the great feudal empires, of religion, and also other forms of social cohesion and solidarity. The demolition of values which were considered permanent, on which human society was based for the past several thousands of years, and the pace of the change that occurred intensively in the $20^{\text {th }}$ century, represent the characteristic that led to the epochal changes, as well as the changes in power relations in the world.

Such changes were characterized by secularization, the availability of education and technology to all residents, the increase in the standard of living, faster physical and virtual communication, the flow of knowledge and capital, competition, globalization of the world, the spread of human right and freedom and many other achievements. They were all the potential for an unseen development. This potential reflected in all areas, and it would be unjust not to mention the great rise of the human race which resulted in the presence of man beyond the boundaries of Earth. Great inventions in all fields of life, including medicine, led to an increasing life expectancy and an increase in living standards led to a demographic "explosion" which became particularly expressed in the second half of the $20^{\text {th }}$ century and it has multiplied the population of our planet. Such an intensive development obviously contributed to the environmental imbalance, where the ecological problems are being very much expressed and they are being on the "other side" with many other negative consequences that are often concealed and represent the price of irrational spending of limited resources. Climate change is only one part of the threats to the modern society.

\section{Hostile Serbia as the Piedmont of the Balkans}

The $20^{\text {th }}$ century in the area of the Balkans, as an imaginary space which has a more symbolic than geographical significance, has left open questions about the formation of the nation state. The process of formation of nation states in Europe (France) begins after 1979. In this process, the formation of a nation was often treated as a formation of an "imagined community" (Anderson), but there is no doubt that the international order, based on the sovereignty of people(known as "the right to self-determination") established a nation state which appears on the ruins of feudal empires (Katunovic, 2003, 96-98). Of course, the principle of "one (majority) nation- one country" has opened a Pandora's Box where the territorial pretensions and the concept of "one nation" collide and leave room for interpretations which last up until today. Bosnia and Herzegovina is (once again) in the

Epiphany: Journal of Transdisciplinary Studies, Vol. 7. No. 2, (2014) (C) Faculty of Arts and Social Sciences 
spotlight. The inevitable departure of the Ottomans from the Balkans in the $19^{\text {th }}$ century was accompanied by numerous remains of a century-long presence which left traces in all spheres of life and they are inevitably recognized even now. This "transition" occurred at a time when even within the Ottoman state the "national question" was questioned, and the ideas of the Young Turks were gaining strength and dominance.

Multi-ethnic empire had another form of internal solidarity (monarchist Sultan's authority) which unified the Caliphate character in yet another community that has not been sufficiently explored, and whose scope is usually minimized by artificial means. That is the Muslim community, and it is consisted of followers of Islam. They represent a real force, but through colonial conquests, the concept of nation made these countries primarily nation states formed by colonial borders and only optionally a part of a Muslim community which has no significance in power relations of the world. On the contrary, since the occupation of Iraq and Palestine (made under the form of "liberation" by one of the major Entente powers- Great Britain) it has been shown that by breaking the solidarity of this kind of community, at the expense of formation of states such as Saudi Arabia, there is a possibility that the defense of some of the most important cultural foundations of the Islamic community would be lost. Defense of Gaza by the Ottoman army during the First World War was the last true defense of the indigenous inhabitants of Palestine. Unfortunately, the solidarity of other Islamic countries was completely left out. This is something that is repeated in the $21^{\text {st }}$ century, which shows that this kind of community withdrew itself before the enchanting idea of "its own nation" and "its own country". It is so far clear that the idea of a nation and "own country" has opened many possibilities for defining the "unification of one nation" but even more for the definition of the "nation state". This happened before and after the First World War (More: Sokolovic, 2014).

During the formation of nation states in the late $19^{\text {th }}$ century and in the process of liberation before and after the WWI, Bosnia had a great misfortune that its state uniqueness before the arrival of the Ottomans (medieval Bosnian state), which was also accepted by the Ottoman and Austro-Hungarian governments, failed to endure at this time. Namely we can agree with Milenko Markovic (2008) that there were continuing aspirations towards $\mathrm{B} \& \mathrm{H}$, solely because its 2 main neighbors (Serbia and Croatia) did not fully profit in terms of definitely rounded national territory. In our opinion, the basic element of the disagreement between these two countries was not the "hatred" among Serbs and Croats but rather to whom should Bosnia belong to. Territorial aspirations of both sides could be observed in continuity. Milenko Markovic says: "these claims remained unrealized over the centuries, firstly because Bosnian state uniqueness and multi-ethnicity refused to accept them, and secondly because the external factor was opposed to them as well."

Bosnia, however, gained its state uniqueness during the Middle Ages along with the existence of Serbian and Croatian states. During the Kotromanic dynasty, and even

Epiphany: Journal of Transdisciplinary Studies, Vol. 7. No. 2, (2014) (C Faculty of Arts and Social Sciences 
more during the time of King Tvrtko, Bosnia was (in addition to Dusan's empire) the largest country in the Balkans and it remained independent for the longest period of time. The second thing that history verifies is the fact that Bosnia, with the exception of some of its smaller parts, has never been part of any Serbian nor Croatian state (except during the years of WWII when the Germans and Italians put B\&H under the jurisdiction of Pavelic's Independent State of Croatia). Otherwise, Bosnian territorial and multi-ethnic distinctiveness was respected by both empires that ruled over it-Turkey and AustriaHungary (Markovic, 2008).

\section{The Serbian and Croatian Undefined Boundaries}

In the situation of undefined territory, especially of the nation state of Serbia (which has lasted up to the modern era) there is a constant threat because of the tendency of encouraging "the Serbs across the river Drina" to revolt, to develop a specific patriotic feeling in which the "special Serbism" is highlighted and this crashes any patriotic attachments of the Orthodox population of B\&H to the country where they were born and lived, as well as many of their ancestors. Such strategy, which is clearly supported by each government in Serbia, runs from the second half of the $19^{\text {th }}$ century, the whole $20^{\text {th }}$ and the beginning of the $21^{\text {st }}$ century, and it reflects the ideas of Serbia as a nation state which should have maximum territory.

The concept of so-called "Great Serbia" is often perceived as as a national state of all Serbs. Besides the well known documents such as the famous "Načertanija" by Ilija Garasanin (1844), there are numerous moves that indicate the ambiguous idea of joining the territory of Bosnia and Herzegovina, Montenegro, Macedonia as well as parts of Croatia to this new state. Serbia's interest for liberation of other "South Slavic brothers" was in the function of that national goal mainly as a project for the expansion of Serbian state. Serbia always favored the idea of unitary concept and not any kind of federation or co-federalization. The most common argument was the accomplished advantage of the power of weapons and force of the population number rather than any achievements of democracy (Markovic, 2008). This approach, along with Croatian aspirations, is one of the main reasons for the failure of the first and second Yugoslavia. In 1899 a book by Miroslav Spalajkovic "La Bosnie et l' Herzegovine "was published in Paris, and it was a doctoral dissertation defended three years earlier. This book claimed that Bosnia and Herzegovina contains "the most valuable part of the Serbian race", and gaining Bosnia is an existential issue for Serbia (Sehic, 2014).

Throughout this period, which has reflected the idea of the nation-state as the European project, the characteristics of the great empires which had a lot of influence on the events in the Balkans were under attack. It is their multicultural character, multi-ethnic composition, which had survived and had become the main obstacle to the idea of a nation that was a substitute for repressed religion, and its flammable content had given strength

Epiphany: Journal of Transdisciplinary Studies, Vol. 7. No. 2, (2014) (C Faculty of Arts and Social Sciences 
to various imposed movements.

In the very center of the empires, there was a victory of the national idea and thus the nation state itself, from the German, Hungarian to the Russian or Turkish national state. This kind of a new world image profiling in which the dominant nation state was able to mobilize millions of people who would go to war not for the idea of a community of nations, but for a union of states and above all in the name of their own nation. Although the worldwide organization (UN) has a name which resembles the "united nations", it is in its essence, the unity of its state members-mostly national states. This applies to the European Union in its modern form, where the insistence on standards, legislation and unification even of the human rights by certain cultural rules, is a recognition of the very ideas that simply overwrite the boundaries of the former multi-ethnic empires. The First World War was used as an anvil on which the nation states were forged and developed; the remains of the monarchist government were more part of the folklore.

After the introduction of a compulsory military service, Bosnia and Herzegovina had a significant participation in Austro-Hungarian army. Before the end of the 1917 there were 298,773 soldiers in Bosnian troops. It is interesting that in all the records, the members of these troops were appointed as Bosnians, a mark for all religions and peoples of Bosnia and Herzegovina. Heroism that characterized these troops has led thousands of young men into death. In this war, Austria-Hungary mobilized $17.2 \%$ of the total male population in Bosnia between the age of 16 and 70. The multi-religious Bosnianhood, as a concept advocated by Austria-Hungary in an attempt to return this medieval concept into a collective memory, experienced a collapse with the growth of national movements and it was definitely abandoned with the disappearance of Austria-Hungary from the world scene.

Bosnia and Herzegovina brought its own uniqueness into the new state of Slovenes, Croats and Serbs, which was a community of Yugoslavian people (again multiethnic!), but this uniqueness was not appreciated by the new authorities. This agreement between Serbs, Croats, and Slovenes, at the time when nation-states were being determined all around Europe, the colonial Africa, but also around the world, has delayed the implementation of the concept of nation state in B\&H. The tendencies of Bosnia's two neighboring countries were expressed through the "implication" of special connections between Bosnian Serbs and Croats, as well as the attempt to separate all the territory from Bosnia and Herzegovina and to merge it with Serbia (more open and evident effort) and Croatia. These aspirations were continuous and they were shaken by the affirmation of Bosnian statehood in the 1974 Constitution which resulted in an attempt to terminate it with aggression and genocide against B\&H from 1992-1995.

\section{Conclusion}


The shots fired in Sarajevo, in 1914, symbolically marked the victory of the national state over the monarchist multiethnic empire. The historical paradox in this case is that this happened in the capital city of a country that will withstand great difficulty and destruction during the twentieth century, just to defend the idea of multi-ethnicity. Bosniaks, people who are gathered around this national name (still more names than national ideologies) at the end of the twentieth and the beginning of the twenty first century, are the majority population in Bosnia. They are mainly Muslims, one of the largest and most persistent (potentially) state-building groups in the "heart of Europe". As such, and in addition being in a struggle for multi-ethnicity, they have been labeled as "others" in Europe which mainly consisted of one nation states. Different geostrategic policies of the most powerful economic, political, and military powers are intertwined in a historical continuity over the territory of Bosnia and Herzegovina and the Balkans, and an interesting fact is that no one is satisfied with anyone's advantage. The qualification of the Balkans (Southeast Europe) as the "other" shows yet another constant that becomes evident when it comes to the concept of nation state and that is, that in its implementation both Orthodoxy (Orthodox Christianity) and Islam are beyond the standard form of the nation state constitution.

The Orthodox people have a predominant theory of the nation as a community of blood and soil and they try to define their countries as larger by placing "predestined" and "historical" rights over other territories, and this leads to a myth production that causes territorial ambiguity, e.g. Russia, Serbia, Ukraine, Romania, Bulgaria... In Muslim majority countries the idea of the nation state was imposed as a part of a standard and enforced colonial relationship in which the ruling concept is based on the nation state and it sets the affiliation to a much wider community of Muslims. All of this causes various problems and holds back the idea of a "new world order", or the idea of liberal democracy and free market as the "end of history." (Fukuyama).

Forced transitions and the imposition of various models are common, and it is evident that Bosniaks in Bosnia and Herzegovina became cross-eyed ever since the departure of the Ottomans, with one eye looking towards Istanbul and with the other towards the upcoming West, and out of the corners of their eyes trying to identify the threats from the neighborhood. We can agree with Abdulgafar Velic that in all these years, from the time of occupation, annexation, the First World War but also in the Kingdom of Yugoslavia, they built their identity on faith. As a result, the terms own country and nation, as represented in European culture, were set in the background (Velic, 2013:168). This prevented Bosnians to plan their conquests towards their neighbors, but also it developed a tolerance and acceptance of others who are different and this was a characteristic of Bosnia and Herzegovina. Bosnians were among the first in Europe who publically were opposed to Fascism (Bandzovic, 2010), and the fact that the elements of multiethnicity and multiculturalism held the pressure in the recent aggression (1992-1995) says that although the concept of coexistence of difference in one area could be a potential 
alternative to the processes that produce conflicts, still these conflicts are becoming even more monstrous by the number of its victims and destruction. Dzemal Sokolovic (2014) has a point when he states that with the shots of Gavrilo Princip in Sarajevo, Europe shot itself, she entered the field of intolerance, bloody conflicts, totalitarian ideologies such as Fascism and Stalinism, holocaust and genocide, where victims are counted in hundreds of millions. Therefore, in our opinion, we should reroute this dilemma about the $100^{\text {th }}$ anniversary of the First World War, and switch it to another domain: whether the assassins are terrorists or heroes?

They were the product and the weapon in the forging of new national boundaries, and without doubt, the shots in Sarajevo represent a real media bomb in those flammable times which were preceded by atrocities of the First and Second Balkan War. That was a preparation and introduction to the Great War which was vigorously knocking on the door as a solution to the "national question" of this, or that nation. It turned out that all of the ideas such as pan-Slavic, South Slavic, pan-Islamic, pan-Arab, have lost the battle with the nation state which still tries to line new boundaries, open new settlements in Gaza, rattle arms around Crimea, Donetsk, Kashmir, Chechnya, Syria, Iraq, imaginary Kurdistan and Nagorno Karabah. It threatens with referendums for secession, introduces the nuclear weapons and gas restrictions, and it intimidates with the triggering of the world war which, according to many, has never ceased to exist from the moment the First World War began.

\section{References}

Bandžović, Safet. 2010. Bošnjaci i antifašizam, Sarajevo.

Engdahl, F.William. 1999. The Century of War (translation), Sarajevo.

Heršak Emil. 1999. Etničnost i povijest, Zagreb, Institute for Migration and Ethnic studies, Edition Jasenski and Turk, Croatian Sociological Association.

Katunarić, Vjeran. 2003. Sporna zajednica (novije terorije o naciji i nacionalizmu. Zagreb: Edition Jasenski and Turk and Croatian Sociological Association.

Marković, Milenko. 2008. Stvaranje i razaranje Jugoslavije, Republika br. 438 - 439 http://www.republika. co.rs/438-439/20.html (visited 09.10.2008.)

Schachinger, Werner. 1996. Bošnjaci dolaze, Sarajevo: Cambi.

Sokolović, Džemal. 2014. „Sukob nacionalne i multietničke države,“ E-novine, feljton od 21.08. 2014. 27.08.2014. http://www.e-novine.com/feljton/ (posjeta 01.09.2014.)

Šehić, Zijad. 2014. „Sarajevski atentant - varnica koja je zapalila svijet,“ Gračanički glasnik, god. XIX br. 37, pp. 27- 94

Velić, Abdulgafar. 2013. Bošnjaci i Evropa, Sarajevo, Dobra knjiga. 